\title{
潜熱・顕熱フラックスの領域平均值 とPatch Scaleの関係 \\ THE RELATIONSHIP BETWEEN REGIONAL AVERAGE OF LATENT AND SEISIBLE HEAT FLUXES, AND PATCH SCALE
}

\author{
葛葉泰久 1 ・早野美智子 2 ・岸井徳雄 3 \\ Yasuhisa KUZUHA, Michiko HAYANO and Tokuo KISHII \\ 1正会員 博士 (工学) 防災科学技術研究所 (テ305-0006 つくば市天王台3-1) \\ (兼)地球フロンティア研究システム (テ105-6791 港区芝浦1-2-1) \\ 2 非会員 博士(学術) 防災科学技術研究所（テ305-0006 つくば市天王台3-1) \\ 3 正会員 博士 (工学) 防災科学技術研究所 (テ305-0006 つくば市天王台3-1)
}

\begin{abstract}
The relationship between regional average of latent/sensible heat flux is discussed. When numerical simulation by Local Circulation Model is carried out, the circulation in the sub-grid region, namely, the area, which is between each grid point, is often ignored. That means that wind speed in the sub-grid is assumed to be much less than background wind. On the other hand, the regional average latent/sensible heat flux from the complex land use surface, which includes several patches, is often estimated by 'weighted average method'. Some researchers have pointed out that this method is available for the patch which scale is less than $10 \mathrm{~km}$.

In this study, some numerical simulations were carried out, under the condition, which was cause of circulation in the sub-grid, and then the effect of patch scale was considered. The main result obtained is that 'weighted average method' is useful, even if patch scale exceeds $10 \mathrm{~km}$. And a few considerations related to 'scale issues' are shown.
\end{abstract}

Key Words: Local circulation model, Scale issues, Latent heat flux, Sensible heat flux, Patch scale, Constant flux layer

\section{1. 序論}

林地等の植生地や裸地からの蒸発散量を把握するこ とは, 水文学・氷資源工学的に「主たる損失項」として非 常に重要である. そのため, 蒸発散量を把握するために, 観測・実験, 数值シミュレーションなどが数多く行われて きた.ここで, 例えば「被覆状態が同じとみなせる領域か らの蒸発散量」を求める場合には, 本研究のテーマであ る,「スケール問題」を考慮する必要はない. しかし, 広 域場に様々な「異なる被覆状態の地表面(以下, 均一場 とみなせるそれぞれの地表面をPatchと称す)がモザイク 状に混在する」場合には, 事情が異なる. すなわち, 各 Patchでの蒸発散量功, 領域平均值を求めねばならず, ここに後述するような「スケール問題」がかかわってくるか らである. 特に, 数值シミュレーションを行う場合, この問 題を考慮することは不可欠である. 著者らは, 琵琶湖流 域を対象とした局地循環モデル(以下，LCMと称す）によ るシミュレーション1)などを行ってきたが，LCMにおけるス ケール問題2も研究対象にしてきた.
LCMでは地表面直近（通常，接地境界層の上端と考え る)の格子点は, 平面的に見て, $1 \mathrm{~km}$ オーダー〜 $100 \mathrm{~km}$ オーダーの間隔で配置される. 今, LCMの水平方向格 子点間隔を $x, y$ 両方向とも $10 \mathrm{~km}$ であるとする. LCM, すな わち大気モデルの最下層格子点(以下，「最下層格子 点」と称す)では, 下方境界条件として, 運動量, 顕熱, 潜熱け3ーラのフラックス、值が必要々なる. これらのフラック スは, 最下層格子点における物理量と, その格子点に対 応する, すなわち直下にある $10 \mathrm{~km}$ 四方の地表面におけ る物理量から計算される.これらのフラックスは,「一つの 最下層格子点と, それに対応する地表面間の平均フラッ クス」(以下, 単に「領域平均フラックス」と称す)であるが, 通常地表面は「複合的に利用された面」であることから， 3つのフラックスを求めるために, 何らかの工夫が必要と なる. 例えば,「一つの最下層格子点に対応する地表 面」を「均一な面」とみなす方法もある. 他に領域平均】 ラックスを求める方法として,「各Patchの面積による加重 平均法 (以下, 単に「加重平均法」と称す)」が提案されて いる例活3).この方法は, LCMの1つの最下層格子点に 対応する地表面が複数の異なるPatchからなる場合に, 


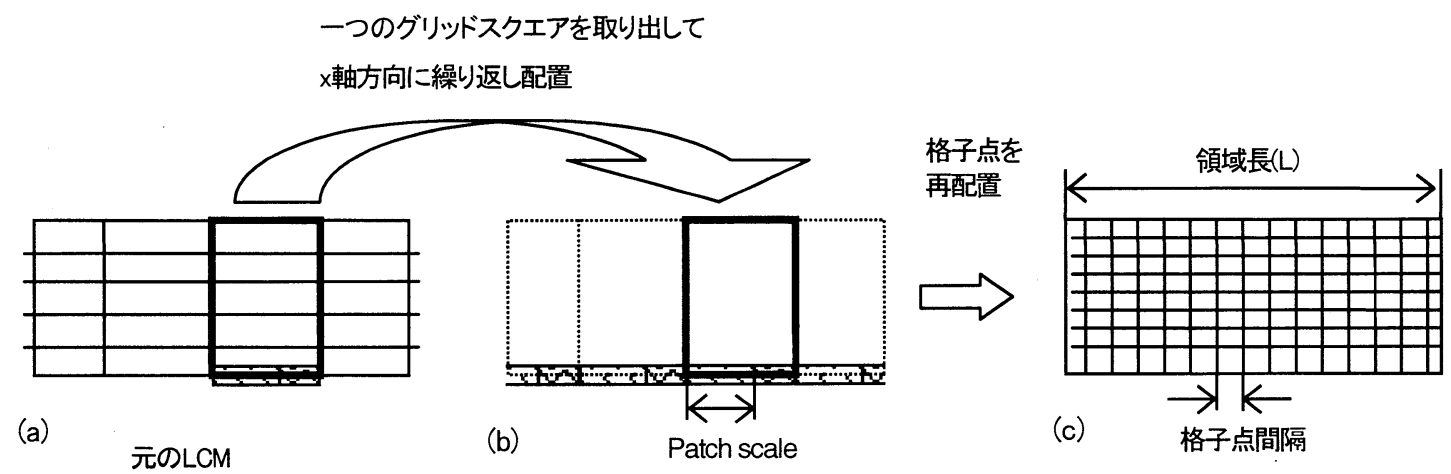

図-1 モデルの基本的コンセプト

「それぞれのPatch - 最下層格子点間」でのフラックスを 個々に求め, それぞれのPatchの面積割合によって加重 平均を行い, 最下層格子点での下部境界条件となる「領 域平均フラックス」を求めるといらものである.

ここで, 10km四方の地表面に, ある被覆状態のPatch (Patch Aとする)と, 別の被覆状態のPatch (Patch Bとす る)が混在すると仮定する. また, Case 1では, 領域が Patch A,Bで半々に分割され(すなわち2つのPatchのみ 存在する)ているとする. それに対して, Case 2では, Patch A,Bの総面積は各々半分ずつであるが，いくつか のPatchがモザイク状に分散しているとする.「加重平均 法」を用いれば, Case 1,2における領域平均フラックスは 同じ值として推定される. ところが実現象では, 必ずしも 同じになるとは限らない. これが, LCMによるシミュレー ションにおける「スケール問題」の一つとなっている.

本論文では,「加重平均法」を用いる際に, Patchのス ケールが, 領域平均フラックスの值に与える影響を調べ ることを目的としている.

なお, 本論文の結果の一部は文献4)ですでに発表ず みであるが，そこではおもに計算結果を示しただけで あった。そこで本論文では追加計算を行い，さらに詳細 な検討を行った.

\section{2. 検討方法}

本研究では, LCMを用いた数值シミュレーションによ る検討を行った. 使用したモデルは2次元モデルで, 木 村5)が開発したものを本研究用に若干変更したものであ る.このモデルはブシネスク近似, 静力学平衡を仮定し たドライモデルであり, 木村らにより多数の研究に用いら れてきた. モデル中の方程式は, 通常用いられるものと 同様なので省略するが(例えば文献5)を参照されたい), 計算に用いられるおもな変数は, 水平風速 (2成分), 垂 直風速, 温位, 比湿である. また, 地表面温度はFRMを 用いて予報し，地表面一最下層格子点間の潜熱フラック スは, いわゆる $\beta$ 法6)を用いた. すなわち, 湿潤度は蒸 発効率 $\beta$ で表現し, 最下層格子点の比湿と地表面の飽
表-1 主な計算条件

\section{共通な条件}

乾燥地の $\beta: 1.0$ 湿潤地の $\beta: 0.0$ 低層スタントン数:0.6

地表面粗度長(運動量):0.5(m) 計算時間 : 48 (hour) 各Caseの条件

Case a 領域長 : $400 \mathrm{~km}$ 格子点間隔： $1 \mathrm{~km}$ Patch Scale: 5(a1), 10(a2), 50(a3), 100(a4) , 200(a5) Km

Case b 領域長 : $4000 \mathrm{~km}$ 格子点間隔 : $10 \mathrm{~km}$ Patch Scale: 100(b1), 200(b2), 500(b3), 1000(b4), 2000(b5)Km

Case c 領域長 :20000 km 格子点間隔 : $50 \mathrm{~km}$ Patch Scale: 1000 (c1), 2500(c2), 5000(c3), 10000 (c4) Km

Case w 領域長 : $4000 \mathrm{~km}$ 格子点間隔 : $1 \mathrm{~km}$ Patch Scale: 10(w1), 50(w2), 100(w3), 500(w3), $1000(w 4), 2000(w 5) \mathrm{km}$

飽和比湿から顕熱フラックスを算定した. 計算は48時間 分行い, その間の $\beta$ は一定とした. 設定条件等は, 表-1 にまとめたとおりである.

本研究の基本的なコンセプト(図-1参照)は次の通りで ある(以下，2次元モデルということを前提ししている)．

LCMで格子点を配置すると, 各格子点での物理量を用 いた計算が行われるが, 隣接する格子点の間, 寸なわち サブグリッド内の現象は特別なパラメタリゼーションを行 わない限り, 表現されない. 通常, LCMにおいては, サ ブグリッドスケールの熱的循環は重視されていない.

ここでは, LCMの ( $\mathrm{xy}$ 平面上の)一つのグリッドスクエア を取り出し，故意にそこで熱循環が起こるような条件を作 り出し, 上述の「加重平均法」による領域平均フラックスが Patchの配置(スケール)の影響をどの程度受けるかを調 べた. 以下，「1つのグリッドスクエアを取り出す」といら表 現を用いるが, これは，図-1(b)に示すように，大きなス ケールのモデルの, 隣接する格子点間領域を取り出すこ とを意味する.ただし, 実際には, 後述するようにモデル の「静力学平衡」の仮定を満たすように, 取り出した領域 をx軸方向に繰り返して配置し(図-(b)), 新たに格子点を 再配置した(図-1(c)) 計算領域を設定している.

具体的には次のような計算を行った. すなわち, $\mathrm{x}$ 方向 に長さLの計算領域を設定し(以下, Lを「領域長」と称 

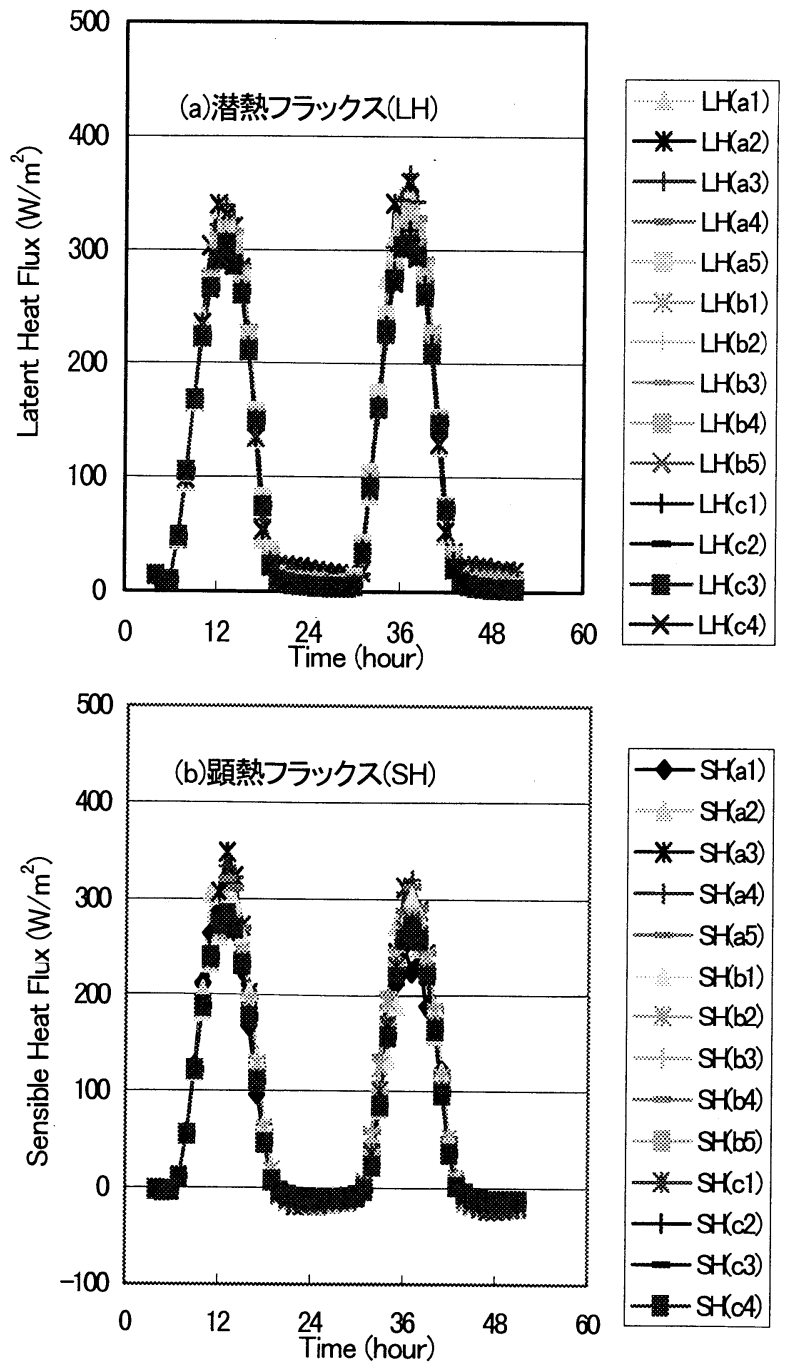

図-2 潜熱・顕熱フラックスの時間変化
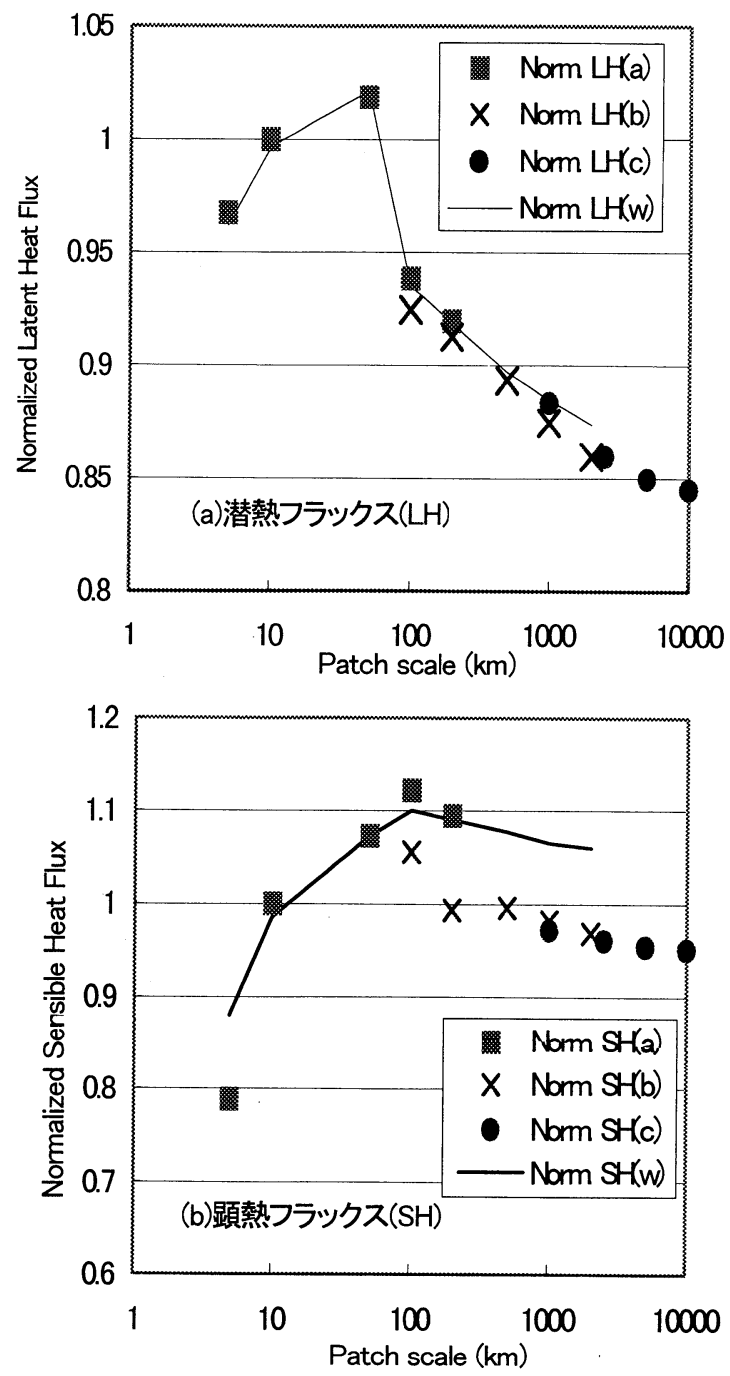

図-3 Patch scaleと正規化されたFlux值の関係 す)，(x方向に総計して) L $/ 2$ の地表面を湿潤地 $(\beta=1)$, $\mathrm{L} / 2$ の領域を乾燥地 $(\beta=0)$ とした. 湿潤地, 乾燥地, 双 方とも領域内に占める総面積(この場合は2次元モデル

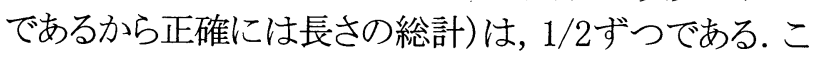
こで, Patch scaleが領域平均(顕熱・潜熱)フラックス值に 与える影響を調べるために, Patchの配置を様々に変え た.

「Case a1」では5kmの乾燥地, 湿潤地を交互に配置し た. 同様に,「Case a2」「Case a3」「Case a4」では, それぞ れ $10 \mathrm{~km}, 50 \mathrm{~km}, 100 \mathrm{~km}$ の乾燥地, 湿潤地を交互に配置し た.「Case a5」では, L=400kmの全領域が, $200 \mathrm{~km}$ 長の乾 燥地, 湿潤地加ら構成される.「Case b」「Case c」「Case w」については, 表-1を参照されたい. なお, 風速の影響 を見るため, それぞれのケースについて, 初期風 $1 \mathrm{~m} / \mathrm{s}$, $5 \mathrm{~m} / \mathrm{s}, 10 \mathrm{~m} / \mathrm{s}$ の通りの計算を行った. $1000 \mathrm{~km}$ 以上の Patchを想定することは，現実的ではないという考え方も あろうが, 傾向を調べるため, また直接の対象とはしてい ないが, GCMsなど, よりスケールの大きなモデルでも結
果の応用が可能なように, あえて, 表-1のような計算条件 を用いたことを付記しておく.

ここで, 領域長 (L)によってCases a,b,c の3つに分け た理由は以下による.

1）たとえば Patch Scale 10kmについて計算する場合, 計算領域内の地表面が「乾燥地」「湿潤地」それぞれ1面

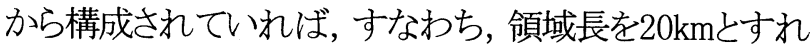
ば良いが, モデルの「静力学平衡」の仮定より, 領域長は ある程度長くとる必要がある. すなわち, Case aの領域長 を400kmとした.

2)この研究では Patch scale $10000 \mathrm{~km} の$ 場合まで計算し たので, Case cでは領域長を20000kmとした.

3)すべての計算をCase c, すなわち領域長 $=20000 \mathrm{~km}$ で 行えば, Patch scaleを小さくした計算をする際, 計算資源 の無駄となる.

なお, Cases a,b,c の様に3つのCasesに分けて計算を 行ったことの妥当性については後で検討している. 

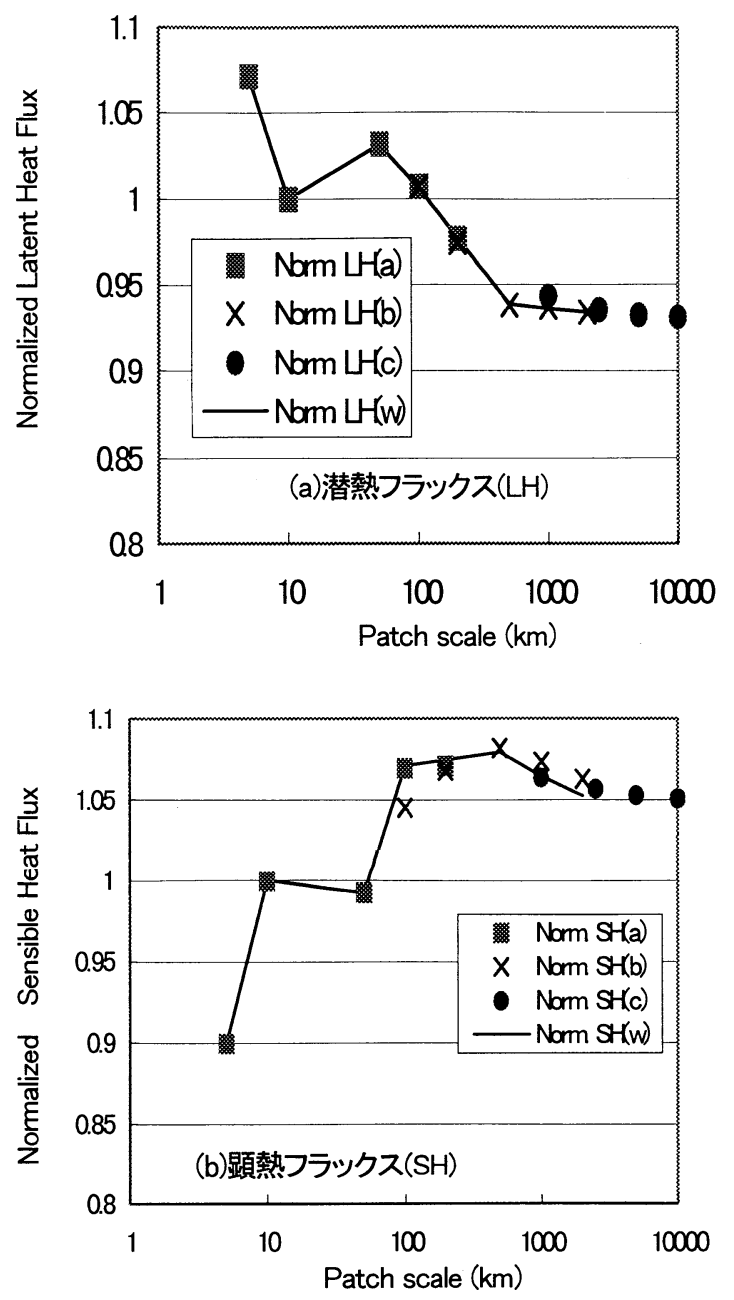

図-4 Patch scaleと正規化されたFlux值の関係

(初期風 $5 \mathrm{~m} / \mathrm{s}$ )
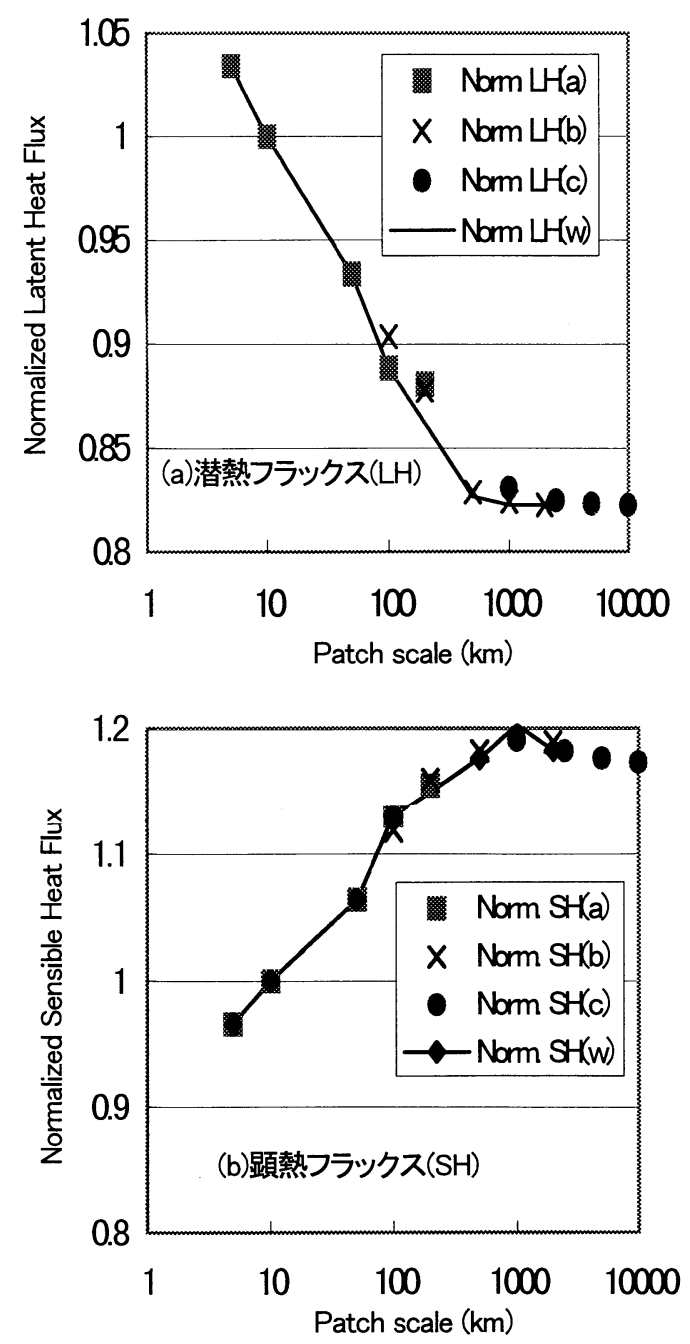

図-5 Patch scaleと正規化されたFlux值の関係

(初期風 $10 \mathrm{~m} / \mathrm{s}$ )

\section{3. 計算結果と考察}

\section{(1) Patch scaleの影響}

図-2(a)(b)は, 初期風 $1 \mathrm{~m} / \mathrm{s}$ の場合の, 潜熱・顕熱フラッ クスの時間変化 (計算開始後48時間分)をプロットしたも のである. X軸の時間は, Local Standard Timeである.た だし24時以降については, 例えば13時を $13+24=37$ 時と 表記している. また, この図中にはPatch scaleが $5 \mathrm{~km}$ 場 合から10000kmのケースまで, 15通りの計算結果を同時 にプロットした。

この図から, 次のようなことがわかる. すなわち,

(a)潜熱・顕熱フラックスとも，12時 (2日目は36時)近辺で もつともPatch scaleの差異による影響が大きく, その近辺 を除けば, Scaleの影響は小さいと考えられる。

(b)夜間はScaleによってフラックスの值が異なるが, 絶対 量が小さいので,この差異は無視できる.

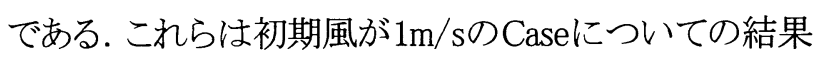
であるが, 初期風が $5 \mathrm{~m} / \mathrm{s}, 10 \mathrm{~m} / \mathrm{s}$ のCaseについても, 類 似の結果を得た. 紙数の制約で図は省略する.

上述(a)のような結果を得たので,つぎに, 2 日目の13時 (LST)での領域平均值の比較を行った. 図-3,4,5におい て, X軸は対数表示したPatch scale $(\mathrm{km}), \mathrm{Y}$ 軸は 13 時 (LST)での領域平均フラックスである.ただし, フラックス 值はPatch scaleが10kmのCase a(2)のフラックス值で正規 化した值である. Patch scale 5kmの場合も, 図中に併記 したが, LCMの静力学的平衡の仮定より, 格子点間隔を $1 \mathrm{~km}$ 未満にすることには問題があると考えた.また一つの Patchが格子点5,6個以上で表現されるのが普通なので, 各図とも, Patch scale $5 \mathrm{~km}$ のケース(格子点間隔 $1 \mathrm{~km}$, 故 に格子点数5個になる) は, 参考值として考えられたい.

図-3(a)は潜熱フラックスに関する図である. 図中の はcase a, すなわち領域長 $400 \mathrm{~km}$, 格子点間隔 $1 \mathrm{~km}$ とした 場合の結果, $\times$, ○はそれぞれ, Case b(同様に領域 $4000 \mathrm{~km}$, 格子点間隔 $10 \mathrm{~km})$, Case $\mathrm{c}(20000 \mathrm{~km}, 50 \mathrm{~km})$ の 


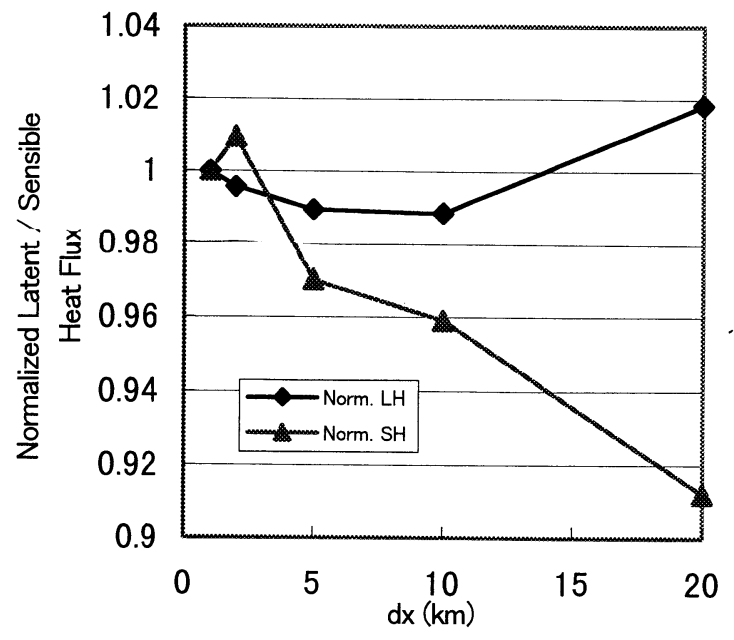

図-6 格子点間隔 $(\mathrm{dx})$ と正規化されたFlux値の関係

結果で, 例えばPatch scale $100 \mathrm{~km}, 200 \mathrm{~km}$ にいては Cases a, bの双方で計算を行った. また, 図-3(b)は同様 の図で, ただし顕熱フラックスに関する図である. また図 -4, 図-5は図-3之同様の図で, 初期風が $5 \mathrm{~m} / \mathrm{s}, 10 \mathrm{~m} / \mathrm{s} の$ 場合の図である. なお以下の議論において, Patch scale $10 \mathrm{~km}$ の場合の計算值を基準に考え, Patch scaleを変化 させた場合のそこからのずれを「誤差」と考えることにす る.これらの3図から，以下のようなことがわかる. すなわ ち,

(c)Patch scale 10kmの計算結果を基準に考え, 20\%の誤 差を許容値とするなら, Patch scaleが10000kmになっても, 潜熱·顕熱フラックス值とも, 許容誤差内の結果が得られ ていると考えられる. 1)計算領域内に熱的循環を故意に 起こすような条件 $(\beta=0, \beta=1$ のPatchを混在させた)下で 行なった計算であること, 2)ここで, 前述の結果(a)に依り, 最も条件の悪い13時(LST)の值を比較したこと，3)実際に は一つのグリッドスクエア内に $10000 \mathrm{~km} の P a t c h か ゙$ 存在す る条件下での計算は行われないだろう，といらことから考 えると, $20 \%$ の誤差を許容限度とするなら, シミュレーショ ンにおいて, Patch scaleの影響を考慮する必要はないと いえる.

(d)誤差の許容限度を $10 \%$ と考えても，おおむねPatch scale $100 \mathrm{~km}$ 以下なら, 熱的循環に起因する影響は小さく, Patch scaleの影響を考える必要はない.

という結果が導かれる. ただし図-3(b)のみ, 3つのCase の計算結果が, らまくオーバーラップしていない. Case b, c の結果はほぼオーバーラップかつ連続しているが, Cases a, bの結果には乘離がある. そこで, すべての Caseについて, Case wなる計算を行った. このCaseの計 算条件は, 表-1に示したとおり, 領域長 $4000 \mathrm{~km}$, 格子点 間隔 $1 \mathrm{~km}$ である. 図-3,4,5中の実線が, その結果である.

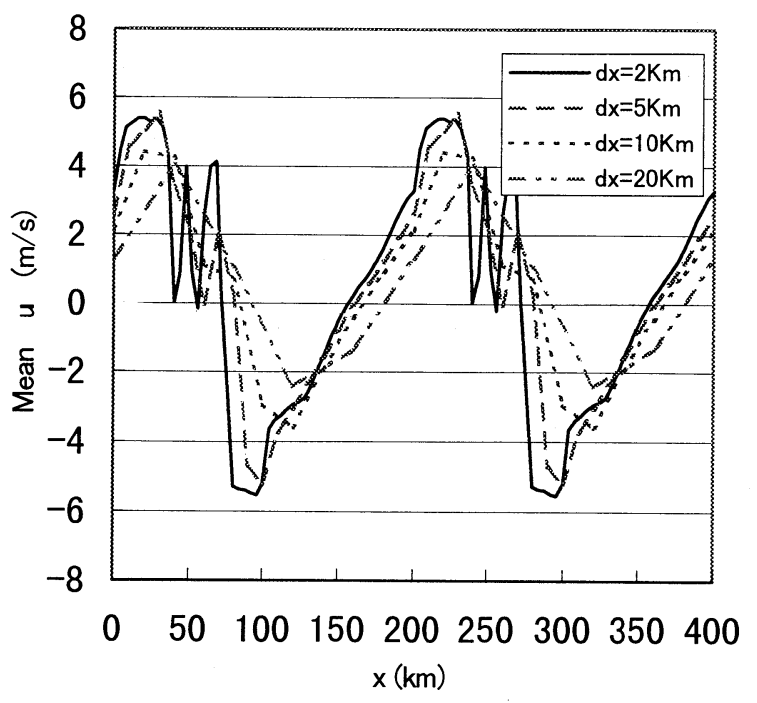

図-7 水平風速分布

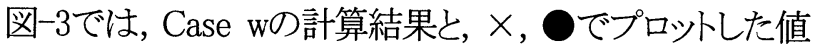
がうまく一致しないが, 図-4,5では, うまく一致している. 格子点間隔がより小さい方が, 現象をより忠実に再現し ていると考えるのが自然であり, それから考えて,

(e)初期風速が小さい場合に, 格子点間隔の違いによる 影響が顕著になる. ある程度以上の初期風速を与えた場 合, すなわち $5 \mathrm{~m} / \mathrm{s}, 10 \mathrm{~m} / \mathrm{s}$ した場合については, 格子 点間隔を領域長に応じて $1 \mathrm{~km} 〜 50 \mathrm{~km}$ と変化させても，そ の影響はほとんどない.

という結果が導かれる. なお, 通常領域長が大きくなれ ば計算資源節約のために格子点間隔を大きくとるのが普 通であり, Case b, cはそれに従った計算を行ったわけで あるから, Case wの結果は, 前述の結果(c),(d)を否定す るものではなく, 格子点間隔を $1 \mathrm{~km} と, よ り$ 細かくしたら, (図-3において) Patch scale 100km以上の場合に, 誤差 がより大きくなった(それでも誤差は10\%以内におさまっ ている)という結果を得たにすぎない.

しかし, 結果(e)は「格子点間隔と潜熱・䫓熱フラックス 算定誤差」といら問題を新たに示しているので, 節を変え てこの検討を行うことにする.

\section{（2）格子点間隔の影響}

前節で述べたように, 初期風速が小さいとき, Case a (格子点間隔 $1 \mathrm{~km})$, Case $b($ 同 $10 \mathrm{Km})$, Case $\mathrm{c}$ (同50Km) の結果(図2-(a),(b))がうまくオーバーラップしなかった。 また, それらの結果は, 格子点間隔 $1 \mathrm{~km} の$ Case wから得 られた曲線上にのらなかった. この理由を,「各Caseの格 子点間隔 $(\mathrm{dx})$ の差に起因する」と仮定し, 以下のような計 算を行った. すなわち,

1)計算条件は $\mathrm{dx}=1 \mathrm{~km}, 2 \mathrm{~km}, 5 \mathrm{~km}, 10 \mathrm{~km}, 20 \mathrm{~km} の 5$ とおりと する. 他の計算条件は, 今までのCaseと同じである. 
2)図2-(b)からわかるように, Patch scale 100kmあたりでこ れらの間の誤差が大きいので, Patch scaleを100kmとし ての計算を行った。

図-6はこれらの計算結果を示したものである. 図一 3,4,5と同様に, 48時間の計算時間中, 2 日目の 13 時 (LST)の值を用い, 潜熱フラックス值, 顕熱フラックス值と も, $\mathrm{dx}=1 \mathrm{~km}$ の Caseの計算值で正規化してある(Y軸). X軸 は格子点間隔 $(\mathrm{dx})$ である.この図から, 以下のようなこと がわかる.すなおち，

(f)図-3(a)においても, 潜熱より顕熱の方が1)各Caseの計 算結果がオーバーラップしない, 2)Case wの結果と一致 しない という傾向が顕著であったが，図-6を見ても潜熱 フラックスに関してはdxの違いの影響はさほど大きくない. (g)顕熱フラックスに関しては, $d x$ の違いの影響がかなり 顕著に出ている.この結果は, 初期風速が小さい場合に は, $\mathrm{dx}$ 設定を慎重に行わなければならないということを 示唆している. ただし, この場合でも, 誤差は高々 $10 \%$ 以 下である.

である.なお, 本節での計算は, Patch scale 100kmで 行ったので, 湿潤地, 乾燥地がそれぞれ2つずつ含まれ るように, 全領域のうち, $400 \mathrm{~km}$ 長の範囲で高度 $10 \mathrm{~m}$ の水 平風速の分布を図-7にプロットした.

この図から, $\mathrm{dx}$ の違いにより, 同じ100kmのPatchでも, 風速場の様相が微妙に異なることがわかる. $\mathrm{dx}$ の変化に より, 風速場が微妙に異なることが示されている.

\section{4. 結論と課題}

従来から用いられている「加重平均法」に関し, Patch scale と「領域平均フラックス」との関係について調べた. LCMではサブグリッド内の風速はbackground windの強さ より十分に小さいことが仮定されている. しかし，LCMに よるシミュレーションの精度を下げる一因として, サブグ リッドスケールの熱的循環が挙げられることは明らかであ る. そこで, 故意に, 熱的循環が大きくなるような条件下, すなわち湿潤地 $(\beta=1)$ と乾燥地 $(\beta=0)$ が交互に隣接す るような条件下でシミュレーションを行った. いわゆる, 海 陸風が吹送しやすい条件である. その結果, 裸地を対象 とし, Patch scaleを10kmとしたCaseと比較する といら条 件下で, 20\%の誤差を許容限度とするなら,「加重平均 法」を使用するにあたって, スケール問題は考慮する必
要がない, 10\%の誤差を許容限度としても, Patch scaleが $100 \mathrm{~km}$ 以下なら, スケールを考慮する必要がないことが わかった.

今後の課題を以下のように考える.

1)土壌(または地表面)モデルだけではなく, 植生モ デルを包含した LCM において同様の検討を行い, こ こで得られた結果より,さらに普遍的な結果を得る必 要がある.

2)例えば文献 3)では,「加重平均法」を用いる際に，1 つの最下層格子点が代表している大気においては， 同一高度の大気は十分に Blend されており, 物理量 が同一であるといら仮定が用いられている. 今回は 1 つのグリッドスクエアを取り出して, さらに細かく格子点 を配置したため,この仮定は用いられていない.この 仮定を用いた場合にも Patch scaleを考慮する必要が ないかどうかを検討する必要がある. 今後はこれらに 関する検討, さらには新しいスキームを開発する研究 を行う。

謝辞：木村富士男筑波大学教授には, 開発された 局地循環モデルの使用を許可していただくとともに， 数々のコメントをいただきました.ここに深謝いたしま す.

\section{参考文献}

1) 葛葉泰久ら: 3次元蒸発散モデルの琵琶湖流域への適用と 2,3 の基礎的検討，水工学論文集，第38巻，pp.137-142， 1994.

2) 葛葉泰久ら：複合場からのフラックス推定 -- 局地循環モ デルに関する基礎的考察 --, 水文・水資源学会誌, Vol. 9, pp.153-161, 1996.

3) Kimura, F: Heat Flux on Mixtures of Different Land-use Surface: Test of a New Parameterization Scheme, J. Meteor. Soc. Japan, Vol. 67, pp.401-409, 1989.

4) 葛葉泰久ら: 局地循環モデルにおける地表面水蒸気フラック 又算定誤差，第53回年講概要集第2部, pp.54-55, 1998.

5) 例えば，木村富士男: 局地風モデルを利用した光化学污染の 数值シミュレーション, 気象研究所技報, Vol.11(7), pp.217295, 1984.

6) 近藤純正（編著）：水環境の気象学, 朝倉書店, 1994.

(1998.9.30受付) 